Vol. 2, No. 2, 2020

https://doi.org/10.23939/jtbp2020.02.084

Orest Voznyak, Yuriy Yurkevych, Iryna Sukholova, Oleksandr Dovbush, Mariana Kasynets

\title{
METHOD OF THE BOILER ROOM VENTILATION SYSTEM EFFICIENCY EXPERIMENTAL DETERMINATION
}

\author{
Lviv Polytechnic National University, \\ Department of Heat and Gas Supply and Ventilation, \\ orest.voznyak@i.ua
}

(C) Voznyak O., Yurkevych Yu., Sukholova I., Dovbush O., Kasynets M., 2020

The issue of the normative air exchange ensuring in the premises of the boiler houses is extremely important. The article presents the results of theoretical and experimental studies of air velocity determination in the distribution of air by round and compact jets in the boiler room. Graphical and analytical dependences are given. The research results substantiate the higher accuracy of the average air flow velocity determination in small boiler rooms. The aim of the work is to develop a method for experimental determination of the efficiency of the ventilation system in the boiler room; to increase of the accuracy of the average velocity determination of the round and the compact air jets in the plane of the supply nozzle to ensure the normative air exchange of the boiler room and to substantiate of the calculation method. The characteristics and patterns of development of round and compact air jets in the premises are established and the calculated dependences are obtained. The unitless integral air velocity for the round and compact air jets in the boiler room is established. Calculation dependences for determining of the air flow rate in the boiler room have been obtained. It is substantiated that the application of the proposed method will significantly increase the accuracy of air exchange determination in the boiler rooms to ensure the required value in accordance with regulatory requirements. Also it is substantiated that to obtain satisfactory experimental results on speed measurements in the boiler room, it is necessary to measure the speed in the center of the supply nozzle several times with maximum accuracy. Then multiply the result by the relative average velocity: for a round jet $v_{a v}=0.26$ and for a compact jet $-v_{a v}=0.2025$. The obtained results allow to avoid a significant error $(19 \%)$ in determining the required air exchange ventilation of the boiler room. Recommendations for the practical determination of the calculated values to ensure proper ventilation of the boiler rooms are given.

Key words: ventilation, flow rate, air distribution, air velocity, round air jet, compact air jet.

\section{Introduction}

Internal microclimate of the premises is determined by the different characteristics (Gumen et al., 2016; Voznyak et al., 2005). So does concentration of $\mathrm{CO}_{2}$ (Kapalo et al., 2018; Kapalo et al., 2019; Kapalo et al., 2014) etc. Internal microclimate of boiler rooms must be according to normative characteristics of indoor air of the boiler premise (Redko et al., 2019; Redko et al., 2018).

In accordance with the current regulations (DBN B.2.5-77:2014) for boiler rooms with excess heat, should provide a ventilation system with natural motivation. If it is impossible to provide the necessary air exchange due to natural ventilation, design ventilation with mechanical motivation. Ventilation systems, methods of supply and removal of air must be taken in accordance with Annex D (DBN B.2.5-77:2014). For premises of built-in boilers and roof boilers running on gaseous fuel, as well as premises of separately located and attached boilers with an area of not more than $200 \mathrm{~m}^{2}$ or height not more than $6 \mathrm{~m}$, it is necessary to provide not less than three air exchanges per hour air consumption for combustion. 
Thus, the conditions of comfort are primarily determined by minimal 3-time air exchange concerning natural air exhaust. Air inflow amount must be some more, because there is needed additional air inflow amount for the gas burning in the boiler furnace (Dovhaliuk \& Mileikovskyi, 2007; Voznyak et al., 2005). This value must be maintained by nature ventilation devices and depends on the designed air exchange structure and air distribution schemes in the boiler premise (Dovhaliuk \& Mileikovskyi, 2008; Voznyak et al., 2019). Combination of all factors determines the nature of the air stream and leakage of air jets in the premise (Dovhaliuk \& Mileikovskyi, 2013; Voznyak et al., 2019).

Therefore, during the commissioning of the boiler house and during the off-season commissioning works, the boiler room ventilation systems are certified for compliance with the estimated costs of supply and exhaust air.

The amount of triple air exchange is usually determined experimentally. The air velocity is measured several times at several points in the cross section of the supply and exhaust vents for further averaging of the results, as well as the area of the vents themselves. Therefore, the performance of the system is analytically determined by the continuity equation. This does not take into account the nature of the inflow jet, its characteristics and features. Because the jet profile is specific, there is a possibility of significant error in the choice of measurement points and their number.

\section{Target of this article}

The aim of the work is to develop a method for experimental determination of the efficiency of the ventilation system in the boiler room; to increase the accuracy of determining the average speed of round and compact air jets in the plane of the supply nozzle to ensure the normative air exchange of the boiler room and to substantiate the calculation method.

\section{Techniques used}

The importance of taking into account the influence of air flow disturbances due to low gabarites of the premise and presence of technological equipment as well supporting personnel in the premise on air velocity distribution and their features, is explored in (Gumen et al., 2016; Dovhaliuk \& Mileikovskyi, 2007; Dovhaliuk \& Mileikovskyi, 2008). In such conditions it is necessary to provide a necessary air exchange in the boiler room. In addition to providing triple natural extraction, the supply of excess supply air for gas combustion should be taken into account, ensuring air balance. One of the directions of ventilation efficiency increasing is using of compact and round inflow and exhaust air jets. (Voznyak et al., 2019). In addition to efficiency increasing it is the phenomenon of a stream laying on the ceiling that influences on the stream field, the expanded flow, the processes of mixing and extinction of velocity in the jet (Kapalo et al., 2019; Kapalo et al., 2014). Therefore, the most rational scheme of air distribution in the case of the presence of process equipment and maintenance staff in a production space of low height is the application of a method of supplying air to the working area by laying round or compact air jets.

In this paper, the compact and round laying air jets are considered, that are directed along an industrial premise of low height in the presence of technological equipment and supporting personel for a dead-end scheme, in which the exhaust holes are situated in the same plane as the incoming hole (Fig. 1).

In this case, the serviced area where people are located, is washed by an induced jet by the return flow. In this connection, the issue of determining the patterns of air flow in the reverse flow becomes of great importance. The main attention in this work is devoted precisely to determination of the average air velocity in the hole of the incoming air flow.

In ventilation technology, air supply is carried out through supply inlets (Fig. 1). Usually free nonisothermal turbulent jets are formed. They can be of different types: round, compact, flat and others.

Free jets do not interfere with their development, and the compressed surfaces are affected by the surface of the premises. If the outlet temperature of the jet from the nozzle coincides with the air 
temperature in the room, the jet is isothermal, and if it does not coincide (higher or lower) - then non-isothermal (heated or cooled). If the criterion $\operatorname{Re}<2300$, then the jet is laminar, and at values of $\operatorname{Re}>10000$ - turbulent.

The flow region with constant velocity and temperature is the core of the jet. Along the axis of the nozzle at a certain distance from its cut is the pole of the jet $\mathrm{O}$. If from it through the boundaries of the cut nozzle to draw rays, we obtain the outer boundaries of the jet.

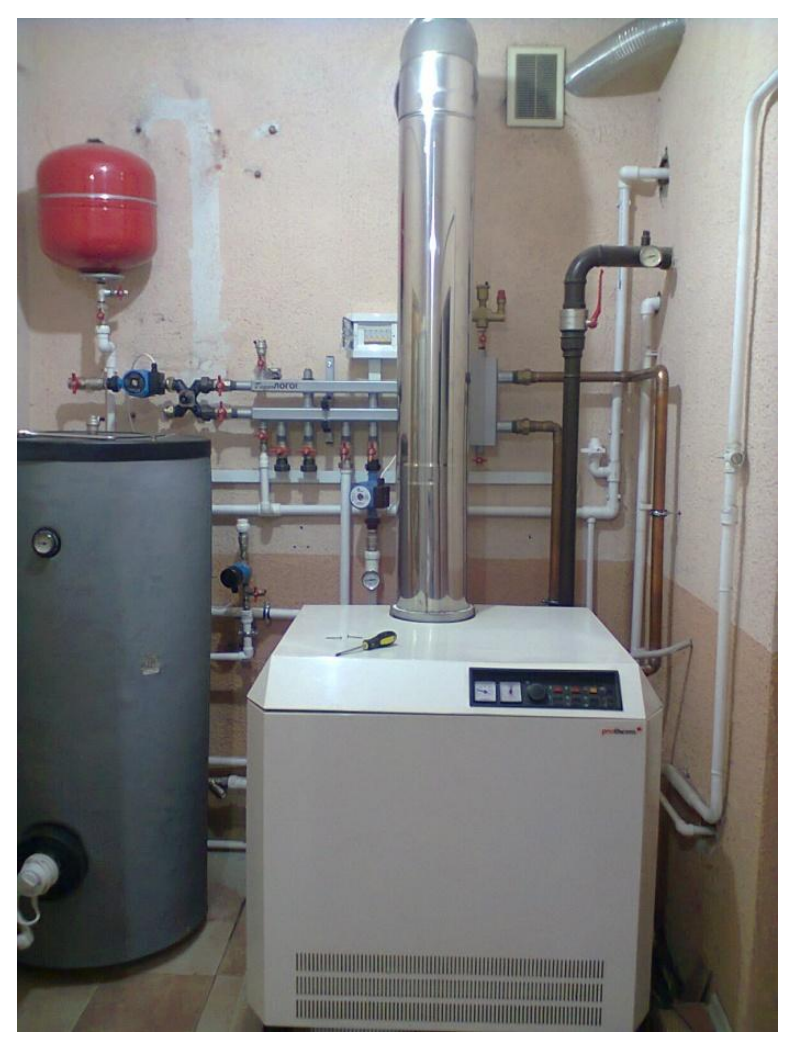

Fig. 1. Boiler room

In the main section, the development of the jet is accompanied by a monotonic drop in the axial velocity $v_{x}$. In isothermal jets, the axial velocity $v_{x}$ is determined by the known formula:

$$
v_{x}=\frac{M}{x}
$$

where $x$ - the flow coordinate; $M$ - dynamic characteristics:

$$
M=\frac{0.66}{\operatorname{tg} \alpha} \sqrt{\frac{T_{b}}{T_{o}}} \cdot \sqrt[4]{\xi} \cdot v_{o} \cdot \sqrt{F_{o}},
$$

where $\alpha$-the angle of opening of the jet, a $\alpha=12^{\circ} 25^{\prime}$, and $\operatorname{tg} \alpha=0.22 ; \xi$-coefficient of local resistance, $\xi=1 ; T_{o}, T_{b}$ - absolute temperatures, respectively, at the outlet of the nozzle and in the room; $v_{o}-$ initial speed, $\mathrm{m} / \mathrm{s} ; F_{o}-$ the area of the supply nozzle, $\mathrm{m}^{2}$.

Rate attenuation coefficient $m$ (Gumen et al., 2016; Dovhaliuk \& Mileikovskyi, 2007; Dovhaliuk \& Mileikovskyi, 2008) is an important parameter, that is determined from (3):

$$
m=\frac{0.66}{\operatorname{tg} \alpha} \sqrt{\frac{T_{B}}{T_{o}}} \cdot \sqrt[4]{\xi} .
$$


Hence the axial velocity $v_{x}$ :

$$
v_{x}=m \cdot v_{o} \cdot \frac{\sqrt{F_{o}}}{x} .
$$

It is known, the velocity profile in the cross section of the free compact air jet has the form as shown in Fig. 3. The velocity $v_{y}$ in any section " $x$ " at a distance " $y$ " from the axis of the free compact jet (Fig. 2) is defined both by the Reichardt and Schlichting theories. The profile of the velocity distribution in the cross section of the free jet obeys the law described by Reichardt's formula, namely:

$$
\frac{v_{y}}{v_{x}}=e^{-0.7\left(\frac{y}{y_{0.5}}\right)^{2}},
$$

where $v_{x}$ and $v_{y}$-axial and transverse velocities, respectively, $\mathrm{m} / \mathrm{s} ; y$-current transverse coordinate, $\mathrm{m}$; $y_{0,5}-\mathrm{a}$ transverse coordinate in which the transverse velocity is equal to half the axial.

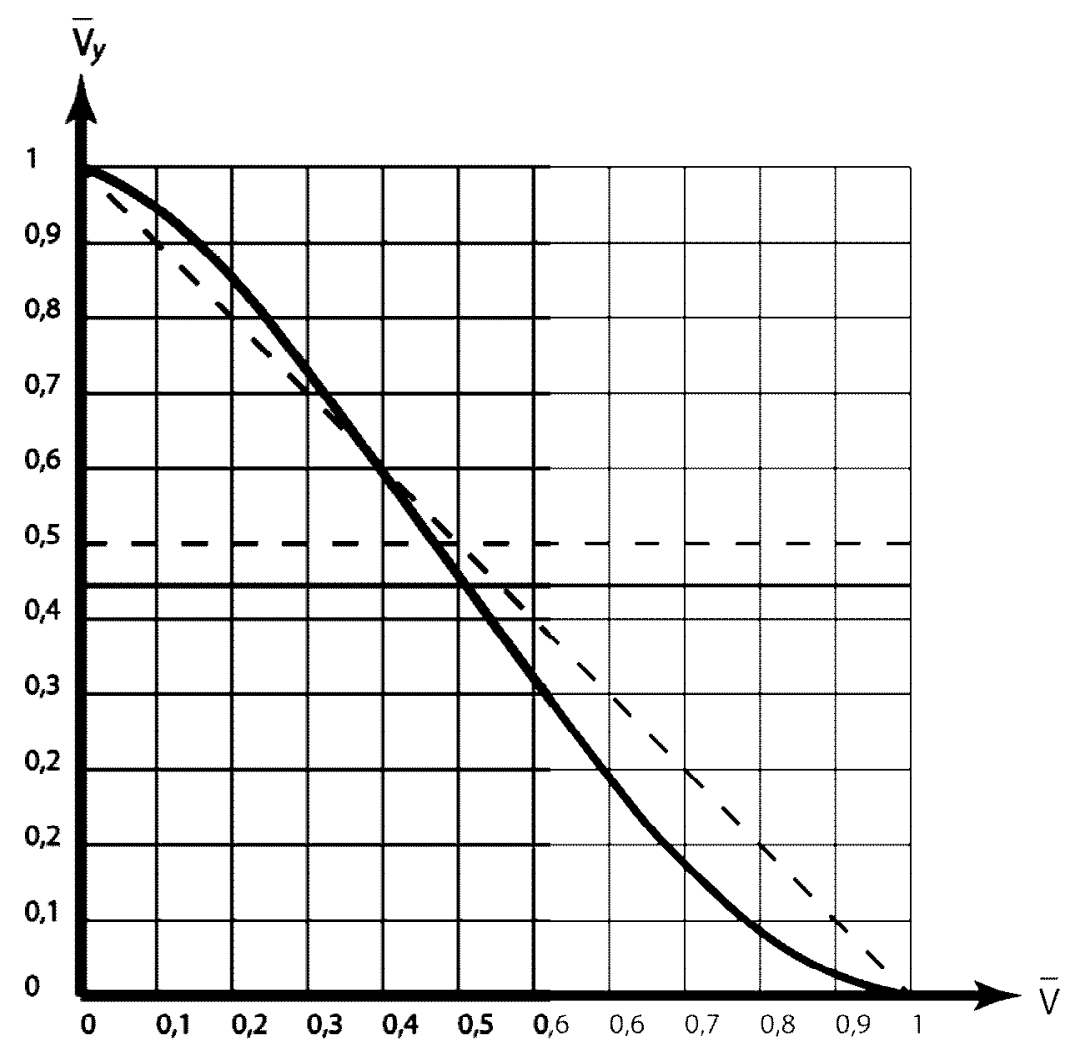

Fig. 2. Dependence of relative velocity on relative transverse coordinate: dashed line - results by traditional methods; solid line - refined results

This theory takes into account that the air velocity does not reach zero near the jet limit. Its disadvantage is that it does not delineate the boundaries of the jet by the nature of the exponent. The jet boundaries are taken into account by Schlichting, but a conditional simplification is considered, that at the jet boundary the velocity is zero, which is not really true. The speed profile is described by the following formula:

$$
v_{y}=v_{x}\left[1-(\bar{y})^{1.5}\right]^{2}
$$

where $\bar{y}$ - the relative transverse coordinate, which is defined as $\bar{y}=\frac{y}{y_{c p}}$, a $y$ and $y_{2 p}$-respectively, the transverse absolute coordinate and the distance to the jet boundary. 
$\overline{v_{y}}$ - the relative transverse velocity determined by (3):

$$
\overline{v_{y}}=\frac{v_{y}}{v_{x}} .
$$

It is advisable to use the relative values of velocities, axial $\bar{v}_{x}=v_{x} / v_{o}$ and in any cross section $\bar{v}_{y}=v_{y} / v_{x}$.

When determining the speed of supply and exhaust jets in the boiler room, the method of performing measurements at several points in the cross section of supply and exhaust holes with their subsequent averaging is generally accepted. But the graph of the axial velocity and the velocity profile (Fig. 2) indicate that when choosing points there is a possibility of error, which can be significant. The article proposes to avoid this phenomenon by determining the integral velocity on the basis of formula (2) for round and compact jets. Since the circular jet is symmetrical, it is advisable to use a multiple integral and polar coordinates. For a compact jet, it is advisable to apply the flat problem twice along mutually perpendicular axes.

For a circular jet, open the brackets in the Schlichting formula and go to the polar coordinates:

$$
v_{\text {інт }}=\int_{0}^{1}\left(1-2 \rho^{1.5}+\rho^{3}\right) \rho d \rho \int_{0}^{2 \pi} d \varphi .
$$

After separating the variables:

$$
v_{\text {інт }}=\int_{0}^{1}\left(\rho-2 \rho^{2.5}+\rho^{4}\right) d \rho \int_{0}^{2 \pi} d \varphi .
$$

We get the result of integration:

$$
v_{\text {iнm }}=\left(0.5 \rho^{2}\left|\frac{1}{0}-\frac{2}{3.5} \rho^{3.5}\right| \begin{array}{l}
1 \\
0
\end{array}+\frac{1}{5} \rho^{5} \mid \begin{array}{l}
1 \\
0
\end{array}\right) 2 \pi .
$$

After substituting the integration limits, we obtain the relative integral velocity $v_{\text {інг }}=0.26 \pi$. The area of the jet $F$ in the plane of the nozzle $F=\pi r^{2}$, ie $\pi$ relative units, $\left(\pi r^{2}\right.$, where $\left.r=1\right)$, so the average relative velocity of the circular jet $v_{\text {cep }}=0.26$.

For a compact jet we use Cartesian coordinates:

$$
v_{\text {інт }}=\int_{0}^{1}\left(1-2 \bar{y}^{-1.5}+\bar{y}^{-3}\right) d \bar{y} .
$$

The result of integration:

$$
v_{i н m}=\bar{y}\left|\frac{1}{0}-\frac{2}{2.5} \bar{y}^{2.5}\right| \frac{1}{0}+\frac{1}{4} \bar{y}^{4} \mid \frac{1}{0} .
$$

After substituting the integration limits, we obtain the relative integral velocity along the axes $O Y$ and $O Z v_{\mathrm{iHr}}=0.45$ and the resulting $v_{\mathrm{iнт}}=0.2025$. The area of the jet $F$ in the plane of the nozzle $F=4 r^{2}$, ie 4 relative units, and the average relative velocity of the circular jet $v_{\text {cep }}=0.2025$.

Comparing the areas of the nozzles and the average velocities of the jets in the plane of the nozzles, we obtain:

$$
\begin{gathered}
\pi r^{2} / 4 r^{2}=\pi / 4=0.785 \\
0.2025 / 0,26=0.779
\end{gathered}
$$

As we can see from the obtained results, there is a satisfactory convergence. 
When using the traditional process of determining the average speed in the plane of the inlet, averaging the measurement results (dashed line in Fig. 2) we obtain $v_{c e p}=0.5$. This result is obtained by integration, i.e determining the area of the triangle, and hence its midline. When considering the actual velocity profile, the integration result is $v_{c e p}=0.45$. In the case of a flat problem, the error is $10 \%$. If we consider the spatial problem for the actual profile, then determining the triple integral we obtain the result $v_{\text {cep }}=0.2025$. Accordingly, the traditional method gives a result of $0.5 \times 0.5=0.25$ with an error of $19 \%$. And this error is not with a shortage, but with a surplus, ie significantly worsens the situation.

Therefore, to obtain satisfactory experimental results on speed measurements in the boiler room, it is necessary to measure the speed in the center of the supply nozzle several times with maximum accuracy. Then multiply the result by the relative average speed: for a round jet $v_{c e p}=0.26$ and for a compact jet $v_{\text {cep }}=0.2025$. To do this, do not use the coordinator, and find the point at the intersection of the diagonals for the compact jet and the point at the intersection of the diameters for the round.

\section{Conclusions}

On the basis of the obtained results we state:

- the unitless integral air velocity for the round and compact air jets in the boiler room is established;

- calculation dependences for determining of the air flow rate in the boiler room have been obtained;

- it is substantiated that to obtain satisfactory experimental results on speed measurements in the boiler room, it is necessary to measure the speed in the center of the supply nozzle several times with maximum accuracy. Then multiply the result by the relative average speed: for a round jet $v_{a v}=0.26$ and for a compact jet $-v_{a v}=0.2025$.

- the obtained results allow to avoid a significant error (19\%) in determining the required air exchange ventilation of the boiler room.

The obtained results allow us to calculate the average velocity of the compact and round air jets in the boiler room and to determine the air flow rate, needed according with normative documents. Application of this method allows to significantly increase the accuracy of air flow rate determination for the boiler room.

\section{References}

Kapalo, P., Domnita, F., Bacotiu, C., \& Spodyniuk, N. (2018). The impact of carbon dioxide concentration on the human health - case study, Journal of Applied Engineering Sciences. Vol. 8, no. 1, 2018, p. 61-66, ISSN 2284-7197, DOI: 10.2478/jaes-2018-0008.

Kapalo, P., Meciarova, L., Vilcekova, S., Burdova, E., Domnita, F., Bacotiu, \& C. Peterfi, K. (2019). Investigation of $\mathrm{CO}_{2}$ production depending on physical activity of students. International Journal of Environmental Health Research. Vol. 29, Issue 1, 31-44. ISSN:09603123. doi:10.1080/09603123.2018.1506570.

Kapalo, P., Sedláková, A., Košicanová, D., Voznyak, O., Lojkovics, J., \& Siroczki, P. (2014). Effect of ventilation on indoor environmental quality in buildings. The 9th International Conference "Environmental Engineering", 2223 May 2014, Vilnius, Lithuania SELECTED PAPERS, eISSN 2029-7092 / eISBN 978-609-457-640-9 Section: Energy for Buildings.

Kapalo, P., Voznyak, O., Yurkevych, Yu., Myroniuk, Kh., \& Sukholova, I. (2018). Ensuring comfort microclimate in the classrooms under condition of the required air exchange. Eastern European Journal of Enterprise Technologies, Vol. 5/10 (95), 6-14. 
Kapalo, P., Vilcekova, S., \& Voznyak, O. (2014).Using experimental measurements the concentrations of carbon dioxide for determining the intensity of ventilation in the rooms. Chemical Engineering Transactions, Vol. 39, 1789-1794.ISBN 978-88-95608-30-3; ISSN 2283-9216.

Kapalo, P., Vilceková, S., Domnita, F., Bacotiu, C., \& Voznyak, O. (2017). Determining the Ventilation Rate inside an Apartment House on the Basis of Measured Carbon Dioxide Concentrations - Case Study, The 10th International Conference on Environmental Engineering, Vilnius, Lithuania, Selected Papers, 30-35.

Redko, A., Dzhyoiev, R., Davidenko, A., Pavlovskaya, A., Pavlovskiy, S., Redko, I., Kulikova, N., Redko, O. (2019). Aerodynamic processes and heat exchange in the furnace of a steam boiler with a secondary emitter. Alexandria Engineering Journal. Volume 58, Issue 1, 89-101.

Redko, A., Kulikova, N., Pavlovskiiy, S., Redko, A. (2018). Simulation and optimization of heat-exchanger parameters of heat pipes by changes of entropy. Heat Transfer Research. Volume 49, Issue 16, 1545-1557.

Voznyak, O., Korbut, V., Davydenko, B., \& Sukholova, I. (2019). Air distribution efficiency in a room by a two-flow device. Proceedings of CEE, Advances in Resourse-saving Technologies and Materials in Civil and Environmental Engineering, Springer, Vol. 47, 526-533.

Voznyak, O., Myroniuk, K., \& Dovbush, O. (2005). Relationship between a Person Heat Exchange and Indoor Climate. Selected scientific Papers 10 $0^{\text {th }}$ Rzeszow-Lviv-Kosice Conference 2005 Supplementary Issue. Technical University of Kosice. 148-152.

Gumen, O. M., Dovhaliuk, V. B., \& Mileikovskyi, V. O. (2016). Determination of the intensity of turbulence of streams with large-scale vortices on the basis of geometric and kinematic analysis of macrostructure. Proc. of Lviv Polytechnic National University: The theory and building practice, No. 844, 76-83 (in Ukrainian).

Dovhaliuk, V. B., \& Mileikovskyi, V. O. (2007). Efficiency of organization of air exchange in heat-stressed premises in compressed conditions. Journal: Building of Ukraine, No. 3, 36. (in Ukrainian).

Dovhaliuk, V. B., \& Mileikovskyi, V. O. (2008). Estimated model of non-isothermal stream, which is laid out on a convex cylindrical surface. Ventilation, Illumination and Heat and Gas Supply: Scientific and Technical Collection, Issue 12, Kyiv, KNUBA, 11-32 (in Ukrainian).

Dovhaliuk V. B., \& Mileikovskyi, V. O. (2013). Analytical studies of the macrostructure of jet currents for calculating energy-efficient systems of air distribution. Energy efficiency in construction and architecture, Issue 4, 11-32 (in Ukrainian).

Boiler rooms. DBN B.2.5-77:2014. State Building Codes of Ukraine. (2014). Kyiv: Ukrarkhbudinform (in Ukrainian).

О. Т. Возняк, Ю. С. Юркевич, І. С. Сухолова, О. М. Довбуш, М. Є. Касинець Національний університет “Львівська політехніка", кафедра теплогазопостачання і вентиляції

\title{
МЕТОД ЕКСПЕРИМЕНТАЛЬНОГО ВИЗНАЧЕННЯ ЕФЕКТИВНОСТІ СИСТЕМИ ВЕНТИЛЯЦІЇ В ПРИМІЩЕННІ КОТЕЛЬНІ
}

\author{
(C) Возняк О. Т., Юркевич Ю. С., Сухолова I. С., Довбуш О. М., Касинеиьь М. С., 2020
}

У статті представлені результати теоретичних та експериментальних досліджень визначення швидкості повітряного потоку при розподілі повітря круглими та компактними струменями у приміщенні котельні, оскільки питання забезпечення нормативного повітрообміну у приміщеннях такого типу є надзвичайно актуальним. Наведені графічні та аналітичні залежності процесу. Результатами досліджень обгрунтовано високу точність визначення середньої швидкості повітряної струмини в малогабаритних приміщеннях котелень. Метою роботи є розробити метод експериментального визна- 
чення ефективності системи вентиляції в приміщенні котельні; підвищити точність визначення середньої швидкості круглих та компактних повітряних струмин у площині припливного насадка для забезпечення нормативного повітрообміну у приміщеннях котелень та обгрунтувати методику розрахунку. Встановлено характеристики та закономірності розвитку круглих та компактних струмин у приміщеннях і отримано відповідні розрахункові залежності. Також визначено, що для отримання задовільних експериментальних результатів при вимірюванні швидкості в котельні необхідно кілька разів виміряти швидкість у центрі живильної форсунки з максимальною точністю, а потім помножити результат на відносну середню швидкість: для круглої струмини $v_{a v}=0,26$, а для компактної струмини $-v_{a v}=$ 0,2025. Обгрунтовано, що застосування запропонованого методу дозволить суттєво підвищити точність визначення повітрообміну у приміщеннях котелень для забезпечення необхідної величини повітрообміну згідно з нормативними вимогами. Наведено рекомендації практичного визначення розрахункових величин для забезпечення належної вентиляції приміщень котелень.

Ключові слова: вентиляція, витрата повітря, повітророзподіл, швидкість повітря, круглий повітряний струмінь, компактна повітряна струмина. 